\title{
Original Documents"Charges of the Right Honorable Ffrancis Earle of Bedford for the Building of the Church in the Coven Garden Begunne the 5th of July, 1631."
}

\section{Rev. J. Stewart}

To cite this article: Rev. J. Stewart (1876) Original Documents“Charges of the Right Honorable Ffrancis Earle of Bedford for the Building of the Church in the Coven Garden Begunne the 5th of July, 1631.", Archaeological Journal, 33:1, 294-294, DOI: 10.1080/00665983.1876.10851743

To link to this article: http://dx.doi.org/10.1080/00665983.1876.10851743

曲 Published online: 14 Jul 2014.

Submit your article to this journal ¿

View related articles $\sqsubset$ 


\section{Driginal 四ocuments.}

" OHARGES OF THE RIGHT HONORABLE FFRANCIS EARLE OF BEDFORD FOR THE BUILDING OF THE CHURCH IN THE COVEN GARDEN BEGUNNE THE 5th OF JULY, 1631." (A small book of 44 pages of paper.)

Communicated by the Rev. J. STEWART.

THIs is the heading of an account of the cost of building the church of St. Paul's, at the south-west end of Covent Garden, where it was erected by Inigo Jones, when the site of the present market was " an airy square enclosed by rails."

The document has been kindly lent for the inspection of the Institute, by 'Thomas J. Wing, Esq.

The structure was destroyed by fire on the 17 th September, 1795, and very little of the original work is left; but the accounts have still some interest, inasmuch as they contain examples of early technical terms used sometimes in their original sense. The following extracts will show how tenaciously professional phraseology is preserved:

ffor Lx. barlings. vli.

ffor 60 beme sparrs. $45 \mathrm{~s}$.

ffor making a fllower to draw out the Tracerie of one of the great collomes. 8li. Is. $10 d$.

The paveing of the Portico with Mitchells square sett wise 1107 foote 5 inches at $8 s$, the foote. . . .

ffor 13 Wainscotts and Clobords for the pannells middle peeres and belexions for both the great doores $8 l i .98 .8 d$.

ffor the Joyners woorke of the Pullpitt with the Type and Collomes to support it. .

To Zachariah Tailor for the carveing worke on the bodye of the Pullpitt on the Cornishments on the inside \& outside of the Tipe the Pedistalls \& Capitalls of the Collomes .... .

. . for a ffont of white Marble with the Pedistalls of Portland stone with a cover of copper inricht with Imbossments \& carveing $30 l i$.

To Thomas Styles for setting in and youlting with Lead the hookes for the doores at the East end of the Church.

ffor putting up the moulding about the bemes \& Purlemes on the Plauceire of the Roufe viij.li.

ffor setting on the hookes of the Roufe x.s.

To Erasmus Marsh for 18 Stirrops \& 36 boults \& forelocks for the butments of the Roufe. . .

ffor 30 boultes forelocks and collers for fastening the ende of the beames \& principalls together. .... 